\title{
Fresh and matured lamb meat quality fed with sunflower seeds and vitamin $\mathrm{E}$
}

\author{
Qualidade da carne in natura e maturada de cordeiros alimentados com grãos de girassol e vitamina $\mathrm{E}$
}

\section{Ronaldo Oliveira Sales ${ }^{\mathrm{I}}$ Américo Garcia da Silva Sobrinho ${ }^{I^{*}}$ Nivea Maria Brancacci Lopes Zeola $^{\mathrm{II}}$ Natália Ludmila Lins Lima ${ }^{\text {II }}$ Gabriela Milani Manzi ${ }^{\text {II }}$ Fabiana Alves de AlmeidaII Viviane Endo ${ }^{\text {II }}$}

\begin{abstract}
The objective of the study is to evaluate meat quality from Ile de France lamb fed diets supplemented with sunflower seeds and vitamin E. Thirty-two lamb weighing initially $15 \mathrm{~kg}$ were housed in individual stalls and slaughtered when body weight reached $32 \mathrm{~kg}$. The treatments consisted of four experimental diets: D1) sugarcane + concentrate without sunflower seeds; D2) sugarcane + concentrate with sunflower seeds; D3) sugarcane + concentrate without sunflower seeds plus $1000 \mathrm{mg}$ vitamin $\mathrm{E} \mathrm{kg}^{-1}$ diet dry matter (DM); and D4) sugarcane + concentrate with sunflower seeds and 1000mg vitamin $E \mathrm{~kg}^{-1}$ diet DM. The parameters temperature, $\mathrm{pH}$, color, cooking loss, shear force and water holding capacity were determined at maturation times of 0, 7 and 14 days on the Longissimus dorsi muscle. Qualitative characteristics of the meat were not affected by the sunflower seed combined with vitamin $E$ diet; however, $p H 24$ hours was affected $(P<0.05)$ by the sunflower seed combined with vitamin $E$ diet. Cooking loss was not significantly influenced $(P>0.05)$ by diet or maturation times. On the other hand, shear force and water holding capacity were significantly affected $(P<0.05)$ by the treatments. The use of vitamin $E$ resulted in lamb meat with higher water holding capacity. Maturation time influenced the parameters $\mathrm{pH}$, color and shear force. Lamb meat that matured for 7 days displayed the lowest shear force.
\end{abstract}

Key words: lamb, maturation, meat quality, sunflower seeds, vitamin $E$.

\section{RESUMO}

O objetivo deste estudo foi avaliar a qualidade da carne de cordeiros Ile de France alimentados com dietas contendo grãos de girassol e vitamina E. Trinta e dois cordeiros pesando inicialmente $15 \mathrm{~kg}$ foram alojados em baias individuais e abatidos ao atingir $32 \mathrm{~kg}$ de peso corporal. Os tratamentos consistiram de quatro dietas experimentais: D1) cana-de-açúcar + concentrado sem grãos de girassol; D2) cana-de-açúcar + concentrado com grãos de girassol; D3) cana-de-açúcar + concentrado grãos de girassol, mais 1000mg de vitamina $E \mathrm{~kg}^{-1}$ de matéria seca (MS) da dieta; e D4) canade-açúcar + concentrado com grãos de girassol e 1000mg de vitamina $E$ dieta $\mathrm{kg}^{-1}$ de MS. Os parâmetros temperatura, $\mathrm{pH}$, cor, perda de peso ao cozimento, força de cisalhamento e capacidade de retenção de água foram determinados nos tempos de maturação de 0, 7 e 14 dias no músculo Longissimus dorsi. As características qualitativas da carne não foram afetadas pelas dietas contendo grãos de girassol combinado com vitamina $E$, no entanto, $p H 24$ horas foi afetado $(P<0,05)$ pela dieta contendo grãos de girassol com vitamina $E$. A perda de peso por cozimento não foi influenciada $(P>0,05)$ pelos tempos de dieta ou de maturação, por outro lado, a força de cisalhamento e capacidade de retenção de água foi significativamente afetada $(P<0,05)$. O uso da vitamina $E$ resultou em carne com maior capacidade de retenção de água. O tempo de maturação influenciou nos parâmetros $\mathrm{pH}$, cor e força de cisalhamento. Carne de cordeiro com 7 dias de maturação apresentou menor força de cisalhamento.

Palavras-chave: cordeiro, grãos de girassol, maturação, qualidade da carne, vitamina $E$.

\section{INTRODUCTION}

Lamb production is highly efficient due to lamb high growth rate. The activity is usually associated with confinement, a practice that can be economically unfeasible due to high feeding costs. In

'Departamento de Zootecnia, Universidade Federal do Ceará (UFC), Fortaleza, CE, Brasil.

"Departamento de Zootecnia, Universidade Estadual Paulista (UNESP), 14388-900, Jaboticabal, SP, Brasil. E-mail: americo@fcav.unesp.br. *Autor para correspondência. 
order to lower production costs, the use of readily available and cheaper food has been recommended as animal diet. Sugarcane has become an option in Brazilian properties, since it is a forage commonly found at low cost. However, its use to feed ruminants can affect consumption because it has low crude protein content ( 2 to $4 \%$ ) and high content of neutral detergent fiber (46 to 51\%) (GALAN \& NUSSIO, 2000). An alternative to meet the nutritional deficiencies of sugarcane is to use oilseed as diet supplement (FERNANDES et al., 2008).

The inclusion of foods rich in linoleic acid (C18:2), such as oilseed in the diet, can affect meat lipid stability by favoring triglycerides oxidation, resulting in rancidity, oxidation, reducing meat shelf life and palatability. There are studies in the literature about vitamin $\mathrm{E}$ ( $\alpha$-tocopherol) role as an effective antioxidant that sequesters free radicals, promotes oxidative stability and meat conservation products. Its intake helps to prevent diseases, stimulate the immune system and modulate degenerative aging processes (BRIGELIUS et al., 2002). $\alpha$-Tocopherol slows the conversion of oxymyoglobin to metmyoglobin in beef thereby slowing the development of an undesirable brown color in displayed beef (LANARI et al., 1994).

Therefore, studies aiming to use inexpensive foods as source of fatty acids and natural antioxidants to improve the quality of lamb meat are welcome considering the benefits that functional foods bring to human health. The aim of this work was to determine the parameters temperature, $\mathrm{pH}$, color, cooking loss, shear force and water holding capacity determined at maturation times of 0,7 and 14 days on the Longissimus dorsi muscle of lamb fed with sunflower seeds and vitamin $\mathrm{E}$.

\section{MATERIAL AND METHODS}

The experiment was conducted in the Faculdade de Ciências Agrárias e Veterinárias (FCAV), Unesp, Jaboticabal, SP. Field experimental steps, slaughtering of the lamb, as well as $\mathrm{pH}$, temperature and color measurements were realized at the Setor de Ovinocultura of the Departamento de Zootecnia, Unesp. All other qualitative parameters (weight cooking losses, shear force and water holding capacity) were determined in the Laboratório de Tecnologia dos Produtos de Origem Animal of the Departamento de Tecnologia, Unesp.

We used 32 Ile de France lambs, weanling, non-castrated males, weighing average $15 \mathrm{~kg}$. The animals were housed in covered individual stalls with suspended slatted floors of approximately $1.0 \mathrm{~m}^{2}$, equipped with individual feeder and drinker. The lamb were identified, dewormed, supplemented with vitamins $\mathrm{A}, \mathrm{D}$ and $\mathrm{E}$, and remained for 14 days in pre-trial period. The treatments consisted of the following diets: D1) sugarcane + concentrate without sunflower seeds; D2) sugarcane + concentrate with sunflower seeds; D3) sugarcane + concentrate without sunflower seeds plus 1000mg vitamin $\mathrm{E} \mathrm{kg}^{-1}$ diet dry matter (DM); and D4) sugarcane + concentrate with sunflower seeds and $1000 \mathrm{mg}$ vitamin $\mathrm{E} \mathrm{kg}^{-1}$ diet DM. The sugarcane used in the diet was the IAC 86-2480 forage variety, chopped into $1 \mathrm{~cm}$ slices and supplied in natura, the volume:diet concentrate ratio was 50:50, and was offered freely from $8 \mathrm{~h}$ to $17 \mathrm{~h}$. Daily consumption was given by the weight difference between the food offered and the leftover. The composition of lamb diets are presented in table 1 , according to NRC (2006).

The lambs were slaughtered when body weight reached $32 \mathrm{~kg}$, after 16 hours fasting. The lambs were stunned by a $220 \mathrm{~V}$ electric discharge during 3 seconds, followed by the bleeding of the jugular vein and carotid arteries. The carcasses were cooled in a refrigerator at $6^{\circ} \mathrm{C}$ for 24 hours. Temperature, $\mathrm{pH}$ (penetration electrode) and color (Minolta CR-400 colorimeter) were measured on the Longissimus dorsi muscle, before and after the cooling. Visual score for color was determined by the coordinates $\mathrm{L}^{*}$ lightness, $\mathrm{a}^{*}$ redness and $\mathrm{b}^{*}$ yellowness (KNIGHT \& DEATH, 1999). Subsequently, the carcasses were split into two halves, and the left half split into five anatomical regions: neck, shoulder, ribs, loin and leg according to SILVASOBRINHO (2001).

The values of $\mathrm{pH}$, temperature and color were determined on samples in natura of the Longissimus dorsi muscle. Samples of the same muscle were vacuum-packed and kept refrigerated in an B.O.D. incubator at $4^{\circ} \mathrm{C}$ and left to mature for a period of 7 and 14 days. Subsequently, $\mathrm{pH}$, color, weight cooking loss, shear force and water holding capacity were determined on the $7^{\text {th }}$ and $14^{\text {th }}$ days. Temperature and $\mathrm{pH}$ were determined using a $\mathrm{pH}$ meter with penetration electrode. Color was determined by the coordinates $\mathrm{L}^{*}$ lightness, $a^{*}$ redness and $b^{*}$ yellowness using a Minolta CR-400 colorimeter (KNIGHT \& DEATH, 1999). To determine weight cooking loss, meat samples were placed over a grill inside trays, weighed, taken to an oven pre-heated at $170^{\circ} \mathrm{C}$, and broiled to an internal temperature of $75^{\circ} \mathrm{C}$. Once removed from the oven, the baked meat was let to cool down to room temperature and the samples were weighed again to determine weight loss during cooking (OSÓRIO et al., 1998). Subsequently, samples taken from the broiled meat were sheared perpendicular to the muscle fibers using a Warner-Bratzler blade coupled to the Texture Analyzer TA-XT2i to determine 
Table 1 - Chemical composition of the experimental diets used in lamb fed ration supplemented with sunflower seeds and vitamin $\mathrm{E}\left(\mathrm{g} \mathrm{kg}^{-1}\right.$ of dry matter).

\begin{tabular}{|c|c|c|c|c|}
\hline \multirow{2}{*}{ Nutrient } & \multirow[b]{2}{*}{ D1 } & \multirow[b]{2}{*}{ D2 } & \multirow[b]{2}{*}{ D3 } & \multirow[b]{2}{*}{ D4 } \\
\hline & & & & \\
\hline \multicolumn{5}{|l|}{ Percentage } \\
\hline Corn & 79.2 & 2.2 & 78.9 & 2.2 \\
\hline Soyabean meal & 380.5 & 377.5 & 380.5 & 376.6 \\
\hline Sunflower seeds & - & 80.9 & - & 80.8 \\
\hline Sugarcane & 500.0 & 500.0 & 500.0 & 500.0 \\
\hline Mineral feed additives & 4.9 & 4.9 & 4.9 & 4.9 \\
\hline Iodized salt & 3.2 & 3.2 & 3.2 & 3.2 \\
\hline Dicalcium phosphate & 8.1 & 8.1 & 8.1 & 8.1 \\
\hline Urea & 13.2 & 11.5 & 13.3 & 11.5 \\
\hline Calcitic limestone & 10.9 & 11.7 & 10.1 & 11.7 \\
\hline Vitamin E & - & - & 1.0 & 1.0 \\
\hline \multicolumn{5}{|l|}{ Chemical composition $^{\mathrm{b}}$} \\
\hline Dry matter (DM) & 431.4 & 432.3 & 431.4 & 430.4 \\
\hline Crude protein & 235.9 & 233.6 & 235.9 & 233.7 \\
\hline Ash & 65.9 & 67.8 & 65.6 & 68.2 \\
\hline Fat & 14.8 & 33.6 & 14.8 & 33.6 \\
\hline Neutral detergent fiber & 277.2 & 303.0 & 277.2 & 302.7 \\
\hline Acid detergent fiber & 143.1 & 167.1 & 143.1 & 166.9 \\
\hline Metabolizable energy (Mcal kg $\left.{ }^{-1} \mathrm{DM}\right)$ & 3.54 & 3.80 & 3.54 & 3.80 \\
\hline
\end{tabular}

${ }^{a}$ D1: sugarcane + concentrate without sunflower seeds; D2: sugarcane + concentrate with sunflower seeds; D3: sugarcane + concentrate without sunflower seeds plus $1000 \mathrm{mg}$ vitamin $\mathrm{E} \mathrm{kg}^{-1}$ diet dry matter (DM); D4: sugarcane + concentrate with sunflower seeds and 1000mg vitamin $\mathrm{E} \mathrm{kg}^{-1}$ diet DM.

${ }^{\mathrm{b} W e r e}$ realized at the Laboratório Nutrição Animal (FCAV, Unesp).

shear force in $\mathrm{kgf} \mathrm{cm}^{-2}$ (OSÓRIO et al., 1998). Water holding capacity was determined according to methodology described by SILVA SOBRINHO (1999).

The experimental design to evaluate $\mathrm{pH}$, temperature and color, at 45 minutes and 24 hours after slaughtering, was completely randomized, in a $2 \times 2$ factorial (with and without sunflower seeds; 2 levels of vitamin E, 0 and $1,000 \mathrm{mg} \mathrm{kg}^{-1}$ of diet DM). Experimental design for the other variables was completely randomized, with $2 \times 2 \times 3$ factorial (with and without sunflower seeds; 2 levels of vitamin E, 0 and $1,000 \mathrm{mg}$ $\mathrm{kg}^{-1}$ of diet DM; three maturation times: 0, 7 and 14 days). The data were submitted to ANOVA and the means were compared by Tukey test at $5 \%$ significance. The statistical analysis was performed using the program AgroEstat v.1.0 (BARBOSA \& MALDONADO, 2010).

\section{RESULTS AND DISCUSSION}

The treatments did not influence $(\mathrm{P}>0.05)$ $\mathrm{pH}$ at 45 minutes and 24 hours after slaughtering (Table
2). The $\mathrm{pH}$ decrease from 6.56 to 5.62 observed 24 hours after slaughtering is consistent with the rigor mortis process that consists on the stiffening of the muscles after death. SAÑUDO et al. (1998) reported pH values varying from 6.56 to 6.69 at 45 minutes, and from 5.66 to 5.78 at 24 hours, thus indicating no pre-slaughter stress.

Temperature at 45 minutes and 24 hours after slaughtering was not affected $(\mathrm{P}>0.05)$ by different treatments with mean values of $36.37^{\circ} \mathrm{C}$ and $7.57^{\circ} \mathrm{C}$, respectively (Table 3 ). Studying temperature as a function of time on the Longissimus dorsi muscle of Morada Nova lamb during the rigor mortis process, ZEOLA et al. (2007) observed that the temperature drop follows an exponential curve, indicating a rapid drop in the first post mortem hours, followed by a plateau, as observed in this study.

Visual score, redness $\left(\mathrm{a}^{*}\right)$ was different $(\mathrm{P}<0.05)$ in the Longissimus dorsi muscle 24 hours after slaughtering, 13.96 compared to 12.33 for lamb fed diet without and with sunflower seeds. The visual scores $\mathrm{L}^{*}, \mathrm{a}^{*}$ and $\mathrm{b}^{*} 45$ minutes and 24 hours after slaughtering were not $(\mathrm{P}>0.05)$ different (Table 4$)$. While 
Table 2 - Mean values of $\mathrm{pH}$ of the Longissimus dorsi muscle of lamb fed ration supplemented with sunflower seeds and vitamin E.

\begin{tabular}{lll}
\hline Parameter & $(45$ minutes $)$ & $(24$ hours $)$ \\
\hline Vitamin E (E) & & \\
without vitamin E & $6.54 \mathrm{a}$ & $5.46 \mathrm{a}$ \\
with vitamin E & $6.48 \mathrm{a}$ & $5.41 \mathrm{a}$ \\
P & 0.4781 & 0.2603 \\
Sunflower seeds $(\mathrm{G})$ & & \\
Without sunflower seeds & $6.52 \mathrm{a}$ & $5.45 \mathrm{a}$ \\
With sunflower seeds & $6.50 \mathrm{a}$ & $5.42 \mathrm{a}$ \\
$\mathrm{P}$ & 0.8302 & 0.5122 \\
F test interaction E x G & 0.01 & $6.04 *$ \\
P & 0.9051 & 0.0257 \\
VC $(\%)$ & 2.83 & 1.65 \\
\hline
\end{tabular}

Numbers followed by different letters in the column differ by Tukey $(\mathrm{P}<0.05) ; \mathrm{P}=$ probability; $\mathrm{F}$ test for the interaction vitamin $\mathrm{E} \mathrm{x}$ sunflower seeds; $\mathrm{VC}=$ variation coefficient.

studying the effect of different vitamin E levels (300, 400 and $500 \mathrm{mg}$ animal $^{-1}$ day $^{-1}$ ) added to lamb diet, WHEELER \& KOOHMARAIE (1999) did not observe $\operatorname{diet}(\mathrm{P}>0.05)$ effect on meat lightness $\left(\mathrm{L}^{*}\right)$, which was also determined on the Longissimus dorsi muscle, 45 minutes and 24 hours after slaughtering; average $\mathrm{L}^{*}$ score was 41.66 compared to 32.63 in this study.

In this experiment, there was no effect of interaction $(\mathrm{P}>0.05)$ among treatments and maturation times (Table 5). The $\mathrm{pH}$ values varied from 5.53 to 5.63, the highest was observed at 14 days of maturation, while the lowest was observed in the treatment without vitamin $\mathrm{E}$ and at 0 day of maturation. MACIT et al. (2003) studied the influence of maturation on the $\mathrm{pH}$ of the Longissimus dorsi muscle of lamb fed diets supplemented with $45 \mathrm{mg}$ of vitamin E during 75 days and reported no differences $(\mathrm{P}>0.05)$ for color and $\mathrm{pH}$ at maturation times of 2, 4, 7 and 12 days. However, in the group without vitamin $\mathrm{E}$ supplementation, the $\mathrm{pH}$ of meat matured for 12 days was 5.86, higher $(\mathrm{P}<0.01)$ than the $\mathrm{pH}$ values of $5.63,5.64$ and 5.74 for meat matured for 2, 4 and 7 days, respectively.

The visual score lightness (L*) was not affected $(\mathrm{P}>0.05)$ by the diets, but there was difference

Table 3 - Temperature of the Longissimus dorsi muscle of lamb fed diets supplemented or not with sunflower seeds and vitamin E.

\begin{tabular}{lll}
\hline & $(45$ minutes $)$ & $(24$ hours $)$ \\
\hline Pitamin E $(\mathrm{E})$ & & \\
Without vitamin E & $36.09 \mathrm{a}$ & $7.58 \mathrm{a}$ \\
With vitamin E & $36.65 \mathrm{a}$ & $7.57 \mathrm{a}$ \\
$\mathrm{P}$ & 0.7003 & 0.9909 \\
Sunflower seeds $(\mathrm{G})$ & & \\
Without sunflower seeds & $36,37 \mathrm{a}$ & $7,43 \mathrm{a}$ \\
With sunflower seeds & $36,37 \mathrm{a}$ & $7,72 \mathrm{a}$ \\
$\mathrm{P}$ & 0,9972 & 0,8392 \\
VC $(\%)$ & 8,70 & 40,62 \\
\hline
\end{tabular}

Values followed by different letters in the column differ by Tukey $(\mathrm{P}<0.05) ; \mathrm{P}=$ probability; $\mathrm{F}$ test for the interaction vitamin $\mathrm{E} x$ sunflower seeds; $\mathrm{VC}=$ Variance coefficient.

Ciência Rural, v.43, n.1, jan, 2013. 
Table 4 - Visual scores of Longissimus dorsi muscle of lamb fed diets supplemented or not with sunflower seeds and vitamin E.

\begin{tabular}{|c|c|c|c|c|c|c|}
\hline \multirow{2}{*}{ Parameter } & \multicolumn{3}{|c|}{ - } & \multicolumn{3}{|c|}{-------Color (24 hours) } \\
\hline & $\mathrm{L}^{*}$ & $a^{*}$ & $b^{*}$ & $\mathrm{~L}^{*}$ & $a^{*}$ & $b^{*}$ \\
\hline \multicolumn{7}{|l|}{ Vitamin E (E) } \\
\hline Without vitamin $\mathrm{E}$ & $32,06 \mathrm{a}$ & $13,71 \mathrm{a}$ & $1,09 \mathrm{a}$ & $41,08 \mathrm{a}$ & $13,24 \mathrm{a}$ & $1,81 \mathrm{a}$ \\
\hline With vitamin $\mathrm{E}$ & $33,21 \mathrm{a}$ & $11,22 \mathrm{a}$ & $1,23 \mathrm{a}$ & 40,16 a & $13,05 \mathrm{a}$ & $1,59 \mathrm{a}$ \\
\hline$P$ & 0,4322 & 0,2281 & 0,6807 & 0,4360 & 0,7401 & 0,6582 \\
\hline \multicolumn{7}{|l|}{ Sunflower seeds (G) } \\
\hline Without sunflower seeds & $31,13 \mathrm{a}$ & $11,82 \mathrm{a}$ & $1,14 \mathrm{a}$ & $40,75 \mathrm{a}$ & $13,96 \mathrm{a}$ & $1,72 \mathrm{a}$ \\
\hline With sunflower seeds & $34,15 \mathrm{a}$ & $11,11 \mathrm{a}$ & $1,18 \mathrm{a}$ & 40,49 a & $12,33 \mathrm{~b}$ & $1,68 \mathrm{a}$ \\
\hline $\mathrm{P}$ & 0,0513 & 0,0880 & 0,9092 & 0,822 & 0,0139 & 0,9332 \\
\hline $\mathrm{VC}(\%)$ & 9,80 & 7,60 & 64,59 & 6,35 & 10,02 & 63,18 \\
\hline
\end{tabular}

Values followed by different letters in the column differ by Tukey $(\mathrm{P}<0.05) ; \mathrm{P}=$ probability; $\mathrm{F}$ test for the interaction vitamin $\mathrm{E} x$ sunflower seeds; $\mathrm{VC}=$ Variance coefficient. $\mathrm{L}^{*}=$ lightness; $\mathrm{a}^{*}=$ redness and $\mathrm{b}^{*}=$ yellowness.

$(\mathrm{P}<0.05)$ for different maturation times. The highest values 44.19 and 42.66 were observed on the $14^{\text {th }}$ and $7^{\text {th }}$ days, respectively, and did not differ. The supplementation with vitamin $\mathrm{E}$ and maturation time affected $(\mathrm{P}<0.05)$ yellowness $\left(\mathrm{b}^{*}\right)$. The highest $\mathrm{b}^{*}$ value of 4.69 was observed for the diet supplemented with vitamin E. As for maturation time, the highest values were 6.22 and 4.45 on the $14^{\text {th }}$ and $7^{\text {th }}$ days, respectively. These values are close, but were significantly different from 2.07 , the value observed on day 0 . In general, the results for the visual score $\mathrm{L}^{*}$ were lower compared to values reported in the literature that varied from 44.56 to 45.58, at different maturation times (SAÑUDO et al., 1998; SAÑUDO et al., 1998a). In the present study, mean $\mathrm{L}^{*}$ values varied between 40.14 and 44.19 , showing higher brightness.

Table 6 shows that different treatments and maturation times did not affect $(\mathrm{P}>0.05)$ cooking loss, with a mean value of $38.74 \%$. But ZAPATA et al. (2000) reported that as maturation time increased cooking loss

Table 5 - Mean values of $\mathrm{pH}$ and color visual scores of the Longissimus dorsi muscle of lamb fed diets supplemented or not with sunflower seeds and vitamin $\mathrm{E}$ at different maturation times.

\begin{tabular}{|c|c|c|c|c|}
\hline \multirow{2}{*}{ Parameter } & \multirow{2}{*}{$\mathrm{pH}$} & \multicolumn{3}{|c|}{--Color-- } \\
\hline & & $\mathrm{L}^{*}$ & $a^{*}$ & $\mathrm{~b}^{*}$ \\
\hline \multicolumn{5}{|l|}{ Vitamin E (E) } \\
\hline Without vitamin E & $5.53 \mathrm{~b}$ & $41.76 \mathrm{a}$ & $12.35 \mathrm{a}$ & $3.81 \mathrm{~b}$ \\
\hline With vitamin $\mathrm{E}$ & $5.61 \mathrm{a}$ & $42.89 \mathrm{a}$ & $12.09 \mathrm{a}$ & $4.69 \mathrm{a}$ \\
\hline $\mathrm{P}$ & 0.0074 & 0.1403 & 0.7343 & 0.0306 \\
\hline \multicolumn{5}{|l|}{ Sunflower seeds (G) } \\
\hline Without sunflower seeds & $5.56 \mathrm{a}$ & $42.09 \mathrm{a}$ & $12.92 \mathrm{a}$ & $4.00 \mathrm{a}$ \\
\hline With sunflower seeds & $5.59 \mathrm{a}$ & $42.57 \mathrm{a}$ & $11.53 \mathrm{a}$ & $4.49 \mathrm{a}$ \\
\hline $\mathrm{P}$ & 0.2758 & 0.5295 & 0.0745 & 0.1506 \\
\hline \multicolumn{5}{|l|}{ Maturation days (M) } \\
\hline 0 day & $5.53 \mathrm{~b}$ & $40.14 \mathrm{~b}$ & $13.24 \mathrm{a}$ & $2.07 \mathrm{~b}$ \\
\hline 7 days & $5.56 \mathrm{ab}$ & $42.66 \mathrm{a}$ & $12.38 \mathrm{a}$ & $4.45 \mathrm{a}$ \\
\hline 14 days & $5.63 \mathrm{a}$ & $44.19 \mathrm{a}$ & $11.05 \mathrm{a}$ & $6.22 \mathrm{a}$ \\
\hline $\mathrm{P}$ & 0.0140 & 0.0003 & 0.0705 & $<0.0001$ \\
\hline $\mathrm{F}$ test interaction $\mathrm{E} \times \mathrm{G}$ & $1.19 \mathrm{NS}$ & $0.39 \mathrm{NS}$ & $0.01 \mathrm{NS}$ & $11.88^{* *}$ \\
\hline $\mathrm{VC}(\%)$ & $2.01 \%$ & $6.88 \%$ & $24.16 \%$ & $10.26 \%$ \\
\hline
\end{tabular}

Values followed by different letters in the column differ by Tukey $(\mathrm{P}<0.05) ; \mathrm{P}=$ probability; $\mathrm{F}$ test for the interactions vitamin $\mathrm{E} x$ sunflower seeds $\mathrm{x}$ maturation; $\mathrm{VC}=$ Variance coefficient. $\mathrm{L}^{*}=$ lightness; $\mathrm{a}^{*}=$ redness and $\mathrm{b}^{*}=$ yellowness.

Ciência Rural, v.43, n.1, jan, 2013. 
Table 6 - Cooking loss (CL), shear force (SF) and water holding capacity (WHC) mean values determined in the Longissimus dorsi muscle of lamb fed diets supplemented or not with sunflower seeds and vitamin E, at different maturation times.

\begin{tabular}{|c|c|c|c|}
\hline Parameter & $\mathrm{CL}(\%)$ & $\mathrm{SF}\left(\mathrm{kgf} \mathrm{cm}{ }^{-2}\right)$ & $\mathrm{WHC}(\%)$ \\
\hline \multicolumn{4}{|l|}{ Vitamin E (E) } \\
\hline Without vitamin $\mathrm{E}$ & $38.60 \mathrm{a}$ & $1.99 \mathrm{a}$ & $61.06 \mathrm{~b}$ \\
\hline With vitamin $\mathrm{E}$ & $38.87 \mathrm{a}$ & $1.88 \mathrm{a}$ & $63.36 \mathrm{a}$ \\
\hline $\mathrm{P}$ & 0.8659 & 0.4617 & 0.0138 \\
\hline \multicolumn{4}{|l|}{ Sunflower seeds (G) } \\
\hline Without sunflower seeds & $38.86 \mathrm{a}$ & $1.89 \mathrm{a}$ & $61.22 \mathrm{~b}$ \\
\hline With sunflower seeds & $38.61 \mathrm{a}$ & $1.99 \mathrm{a}$ & $63.20 \mathrm{a}$ \\
\hline $\mathrm{P}$ & 0.8739 & 0.5272 & 0.0320 \\
\hline \multicolumn{4}{|l|}{ Maturation times (M) } \\
\hline 0 day & $37.08 \mathrm{a}$ & $2.49 \mathrm{a}$ & $62.90 \mathrm{a}$ \\
\hline 7 days & $38.55 \mathrm{a}$ & $1.61 \mathrm{~b}$ & $61.15 \mathrm{a}$ \\
\hline 14 days & $40.58 \mathrm{a}$ & $1.71 \mathrm{~b}$ & $62.58 \mathrm{a}$ \\
\hline $\mathrm{P}$ & 0.2020 & $<0.0001$ & 0.2444 \\
\hline F test interaction $\mathrm{E} \times \mathrm{G}$ & $4.27 \mathrm{NS}$ & $0.09 \mathrm{NS}$ & $1.53 \mathrm{NS}$ \\
\hline $\mathrm{VC}(\%)$ & $15.77 \%$ & $29.30 \%$ & $5.59 \%$ \\
\hline
\end{tabular}

Values followed by different letters in the column differ by Tukey $(\mathrm{P}<0.05)$; $\mathrm{P}=$ probability; $\mathrm{F}$ test for the interactions ; VC $=$ Variance coefficient.

increased; for in natura lamb meat the loss was $26.96 \%$ while for meat matured during 21 days, the loss was $34.92 \%$. The different treatments did not affect $(\mathrm{P}>0.05)$ shear force $\left(\mathrm{kgf} \mathrm{cm}^{-2}\right)$, however, maturation time did $(\mathrm{P}<0.05)$. The lowest results for shear force, $1.61 \mathrm{kgf}$ $\mathrm{cm}^{-2}$ and $1.71 \mathrm{kgf} \mathrm{cm}^{-2}$ were observed on the $7^{\text {th }}$ and $14^{\text {th }}$ maturation days, respectively and they did not differ.

Maturation time greatly affects shear force measured in the Longissimus dorsi muscle, which the FIELD (1971) associated with the high collagen content of the Longissimus. This fact could be observed in this study since shear force dropped from $2.49 \mathrm{kgf} \mathrm{cm}^{-2}$ to $1.61 \mathrm{kgf} \mathrm{cm}^{-2}$, after 7 days of maturation. The more tender the meat, the less effective the supplementation of diet with vitamin $E$ is (WHEELER \& KOOHMARAIE, 1999). ZAPATA et al. (2000) while determining tenderness of lamb meat from the Longissimus dorsi muscle, observed that non-matured samples had the highest shear force $\left(8.86 \mathrm{kgf} \mathrm{cm}^{-2}\right)$ compared to meat that was matured for 21 days $\left(6.77 \mathrm{kgf} \mathrm{cm}^{-2}\right)$. FRESCURA et al. (2005), while determining meat tenderness of the Longissimus dorsi from Ile de France x Texel lamb raised in confinement and slaughtered at $28 \mathrm{~kg}$, measured a shear force of $3.03 \mathrm{kgf} \mathrm{cm}^{-2}$ for matured meat compared to $4.45 \mathrm{kgf} \mathrm{cm}^{-2}$ for meat in natura. In the present study, shear force varied from 1.61 to $2.49 \mathrm{kgf} \mathrm{cm}^{-2}$ measured in the Longissimus dorsi muscle, considered adequate. However, large variation is found in the literature for this variable, means vary from 1.5 to $15.10 \mathrm{kgf} \mathrm{cm}^{-2}$ (SAÑUDO et al., 1998).

\section{CONCLUSION}

Diet supplementation with sunflower seeds and vitamin $\mathrm{E}$ did not influence meat quality traits $(\mathrm{pH}$, temperature and color) at 45 minutes and 24 hours after slaughtering, while the drop in $\mathrm{pH}$ observed in the Longissimus dorsi muscle was as expected for lamb meat during the rigor mortis process. The addition of vitamin $\mathrm{E}$ to the diet did not affect $\mathrm{pH}$, lightness, redness, cooking loss and shear force; however, it affected yellowness and water holding capacity of lamb meat. Sunflower seeds supplemented in the diet affected only water retention capacity of lamb meat, while all other studied parameters $(\mathrm{pH}$, color, cooking loss and shear force) were not significantly changed, excepting yellowness. Maturation time influenced the parameters $\mathrm{pH}$, color and shear force. Lamb meat that matured for 7 days displayed the lowest shear force.

\section{REFERENCES}

BARbOSA, J.C.; MALDONADO JR, W. AgroEstat: sistema para análises estatísticas de ensaios agronômicos. Jaboticabal: Faculdade de Ciências Agrárias e Veterinárias, Unesp, 2010. Conjunto de programas. 1 CD-ROM.

BRIGELIUS, R.A. et al. The European perspective on vitamin E: current knowledge and future research. American Journal of Clinical Nutrition, v.76, p.703-716, 2002. Disponível em: <http://www.ajen.org/content/76/4/703.full>. Acesso em: 2 maio, 2011. 
FERNANDES, A.R.M. et al. Características da carcaça e da carne de bovinos sob diferentes dietas, em confinamento. Arquivo Brasileiro de Medicina Veterinária e Zootecnia, v.60, p.148-155, 2008. Disponível em: <http://www.scielo.br/ scielo.php?script=sci_arttext \&pid=S0102-0935200800 0100020>. Acesso em: 25 nov. 2011. doi: 10.1590/ S010209352008000100020.

FIELD, R.A. Effect of castration on meat quality and quantity. Journal of Animal Science, v.32, p.845-849, 1971. Disponível em: <http://jas.fass.org/content/32/5/849.full.pdf $+h t m l>$. Acesso em: 16 jun. 2011.

FRESCURA, R.B.M. et al. Sistemas de alimentação na produção de cordeiros para abate aos $28 \mathrm{~kg}$. Revista Brasileira de Zootecnia, v.34, p.1267-1277, 2005. Disponível em: <http:/ /www.scielo.br/scielo.php?script=sci_arttext\&pid=S151635982005000400023>. Acesso em: 20 nov. 2011. doi: $10.1590 / \mathrm{S} 1516-35982005000400023$.

GALAN, V.B.; NUSSIO, L.G. Novos custos para cana-de-açúcar. Boletim do Leite, v.14, 35p, 2000

KNIGHT, T.W.; DEATH, A.F. Effect of dose and frequency of vitamin A supplements, and carry-over effects on plasma carotenoid concentration in steers. New Zealand Journal of Agricultural Research, v.42, p.385-391, 1999. Disponível em: <http:// www.tandfonline.com/doi/pdf/10.1080/00288233.1999.9513387>. Acesso em: 18 jul. 2011. doi: 10.1080/00288233.1999.9513387.

LANARI, M.C. et al. Effect of dietary vitamin E on pigment and lipid stability of frozen beef: a kinetic analysis. Meat Science, v.38, p.3-15, 1994. Disponível em: <http://www.sciencedirect.com/ science/article/pii/0309174094900914>. Acesso em: 12 set. 2011. doi: 10.1016/0309-1740(94)90091-4

MACIT, M. et al. Effects of vitamin E supplementation on fattening performance, non-carcass components and retail cut percentages, and meat quality traits of Awassi lambs. Meat Science, v.64, p.16, 2003. Disponível em: <http://www.sciencedirect.com/science/ article/pii/S0309174002001158>. Acesso em: 7 set. 2011. doi: 10.1016/S0309-1740(02)00115-8.

NATIONAL RESEARCH COUNCIL (NRC). Nutrient requirement of small ruminants. Washington, 2006. 362p.
SAÑUDO, C. et al. Influence of weaning on carcass quality, fatty acid composition and meat quality in intensive lamb production systems. Journal of Animal Science, v.66, p.175187, 1998. Disponível em: <http://journals.cambridge.org/ action $/$ displayFulltext ty pe $=1 \&$ fid $=6949420 \&$ jid $=$ ASC $\&$ volumeId=66\&issueId=01 \&aid $=6949412>$. Acesso em: 12 set. 2011. doi: 10.1017/S1357729800008948.

SAÑUDO, C. et al. Assessment of commercial lamb meat quality of British and Spanish taste panel. Meat Science, v.48, p.91100, 1998a. Disponível em: <http://www.sciencedirect.com/ science/article/pii/S0309174097000806>. Acesso em: 21 maio, 2011. doi: 10.1016/S0309-1740(97)00080-6.

SILVA SOBRINHO, A.G. Body composition and characteristics of carcass from lambs of different genotypes and ages at slaughter. 1999. 54f. Thesis (PostDoctorate in Lamb Meat Production) - Massey University, Palmerston North.

SILVA SOBRINHO, A.G. Criação de ovinos. Jaboticabal: Funep, 2001. 302p.

WHEELER, T.L.; KOOHMARAIE, M. The extent of proteolysis is independent of sarcomere length in lamb Longissimus and Psoas major. Journal of Animal Science, v.77, p.2444-2451, 1999. Disponível em: <http://jas.fass.org/ content/77/9/2444.full.pdf+html $>$. Acesso em: 12 set. 2011.

ZAPATA, J.F.F. et al. Estudo da qualidade da carne ovina do Nordeste brasileiro: propriedades físicas e sensoriais. Ciência e Tecnologia de Alimentos, v.20, p.274-277, 2000. Disponível em: <http:// www.scielo.br/scielo.php? script $=$ sciarttext\&pid $=\mathrm{S} 010$ 120612000000200025>. Acesso em: 20 nov. 2011. doi: 10.1590/ S0101-20612000000200025.

ZEOLA, N.M.B.L. et al. Cor, capacidade de retenção de água e maciez da carne de cordeiro maturada e injetada com cloreto de cálcio. Arquivos Brasileiros de Medicina Veterinária e Zootecnia, v.59, p.1058-1066, 2007. Disponível em: <http:/ /www.scielo.br/scielo.php? script=sciarttext \& pid=S0102$09352007000400036 \& n r m=i s o \& t l n g=p t>$. Acesso em: 18 jul. 2011. doi: 10.1590/S0102-09352007000400036. 